\title{
KOMPOSISI FUNCTIONAL SPECIES GROUP PADA SISTEM SILVIKULTUR TEBANG PILIH TANAM JALUR DI AREA IUPHHK-HA PT. SARPATIM, KALIMANTAN TENGAH
}

\author{
Composition of Functional Species Group at Silviculture System of Tebang Pilih Tanam \\ Jalur in IUPHHK-HA Area of PT. Sarpatim, Central of Kalimantan
}

Prijanto Pamoengkas dan Ayi Kulsum Zamzam

Departemen Silvikultur, Fakultas Kehutanan IPB

\begin{abstract}
Forest management can have an impact on changes in forest structure and composition of plant species. Functional species Group (FSG) may explain the unity of the trees species that are selected in a group in a forest management activities so that it can help in explaining the characteristic of biodiversity such as the quality of habitat and ecosystem processes. The purpose of this research is to know the composition of forest vegetation that the production system are managed with a Silviculture system of TPTJ as seen from the forest structure and composition of the type that belongs to FSG for the stands and natural regeneration in log over area (LOA) and KPPN (The Conservation of Germplasm Area) IUPHHK-HA PT. Sarmiento Parakantja Timber (Sarpatim), Central Kalimantan. Analysis of the composition of the stands type and structure used terraced path in the area of TPTJ and KPPN. The results showed that the types of climax on an entire swath of observations, generally have greater proportion than the group of pioneers, the number of the climax type is 100 while pioneer type is 59. The structure of the stands form a J reverse curve, it show that the composition of vegetation recovery on log over areas managed by using TPTJ and KPPN Silviculture system has balance characteristic of uneven age forest. The value of diversity is high $\left(H^{\prime}>3\right)$. Most of tree and stands community have different communities (ID>50\%).
\end{abstract}

Key words: LOA, FSG, TPTJ, stand structure, composition of species

\section{PENDAHULUAN}

Pengelolaan hutan hujan tropika memiliki resiko terhadap perubahan keseimbangan ekologi dengan berubahnya struktur tegakan dan komposisi jenis karena kegiatan penebangan, pembukaan lahan dan lain-lain (Baker et al. 1987). Keberadaan jenis-jenis tegakan tertentu dalam hutan dapat menjadi indikator tingkat suksesi hutan.

Sistem silvikultur Tebang Pilih Tanam Jalur (TPTJ) merupakan sistem silvikultur hutan alam yang diaplikasikan dengan melakukan penanaman secara jalur pada hutan bekas tebangan atau log over area (LOA). Kegiatan pembinaan hutan dalam sistem TPTJ meliputi pengadaan bibit, penanaman, pemeliharaan dan perlindungan yang dilakukan secara berkesinambungan. Tujuan penerapan sistem silvikultur TPTJ yaitu sebagai upaya untuk meningkatkan produktivitas hutan dengan membangun hutan tanaman meranti yang produktif (Suparna \& Purnomo 2004).

Functional species Group (FSG) merupakan serangkaian jenis yang memiliki pola spesifik serupa dalam penggunaan sumberdaya, respon yang sama terhadap gangguan atau memiliki kelas yang sama dalam tingkat pertumbuhan, kematian dan pemulihan kembali (Gitay \& Noble 1997). Pengetahuan mengenai FSG dapat menjelaskan kesatuan jenis-jenis pohon yang diseleksi dalam suatu kelompok yang berada pada kegiatan pemanenan, pemilihan teknik silvikultur dan sistem manajemen ekosistem, sehingga dapat membantu dalam menjelaskan sifat-sifat biodiversitas seperti kualitas habitat dan proses ekosistem (Pohris 2009).

Evaluasi terhadap penerapan sistem silvikultur TPTJ yang sedang berjalan sampai saat ini perlu dilakukan karena penerapannya belum teruji sampai daur akhir yaitu 35 tahun. Salah satu hal yang dapat dievaluasi yaitu perkembangan vegetasi pada jalur antara penanaman yaitu tegakan alam selebar 17 meter yang diharapkan mampu menjaga kestabilan hutan. Kegiatan penanaman pada area bekas tebangan dapat mempengaruhi perubahan struktur tegakan dan komposisi jenis dengan pembuatan jalur dan kegiatan pemanenan sebelumnya.

Oleh karena itu perlu dilakukan analisis struktur hutan dan komposisi jenis yang dikelompokkan dengan pendekatan komposisi vegetasi, seperti FSG pada area bekas tebangan (LOA) untuk mengetahui proses pemulihan pada tegakan alam di jalur antara dan area hutan tidak terganggu. Penelitian ini bertujuan untuk mengetahui pemulihan komposisi vegetasi hutan produksi yang dikelola dengan sistem Silvikultur TPTJ dilihat dari struktur tegakan dan komposisi jenis yang tergolong FSG untuk tegakan dan permudaan alam di area bekas tebangan (LOA) IUPHHK-HA PT. Sarpatim, Kalimantan Tengah. 


\section{METODE PENELITAN}

\section{Waktu dan lokasi penelitian}

Penelitian dilaksanakan di area kerja IUPHHK-HA PT. Sarpatim, Kalimantan Tengah di area bekas tebangan yang dijadikan model sistem silvikultur TPTJ yang berlangsung dari bulan April sampai dengan Mei 2014

\section{Bahan dan Alat}

Bahan yang digunakan dalam penelitian ini adalah tegakan hutan bekas tebangan pada masing-masing plot TPTJ dan KPPN (Kawasan Pelestarian Plasma Nutfah). Alat-alat yang digunakan dalam penelitian ini adalah phiband, hypsometer, kompas, golok, patok, kantong plastik, sasak, tali tambang, tally sheet, alat tulis, kamera, kertas label dan laptop yang dilengkapi dengan software pendukung seperti: Microsoft Excel 2013 dan Microsoft Word 2013.

\section{Prosedur Penelitian}

\section{Penentuan lokasi penelitian}

Petak ukur pengamatan terdiri dari 12 lokasi berbeda yang didasarkan pada lokasi bekas tebangan yang dijadikan model sistem silvikultur TPTJ dan KPPN yang ada di IUPHHK-HA PT. Sarpatim, Kalimantan Tengah. Masing-masing lokasi tersebut yaitu: Kawasan hutan tidak terganggu (KPPN) yang mewakili hutan primer, petak ukur LOA 9 tahun (76AF dan 76AG), LOA 7 tahun (76AE dan 78AE), LOA 5 tahun (73AH dan 81X), LOA 3 tahun (72AG dan 72AH) dan LOA 1 tahun (94P dan 94Q). Luasan setiap petak ukur yaitu $10000 \mathrm{~m}^{2}$ dan masing-masing petak dilakukan pengukuran pada dua jalur (jalur 2 dan 4) seperti pada Gambar 1.

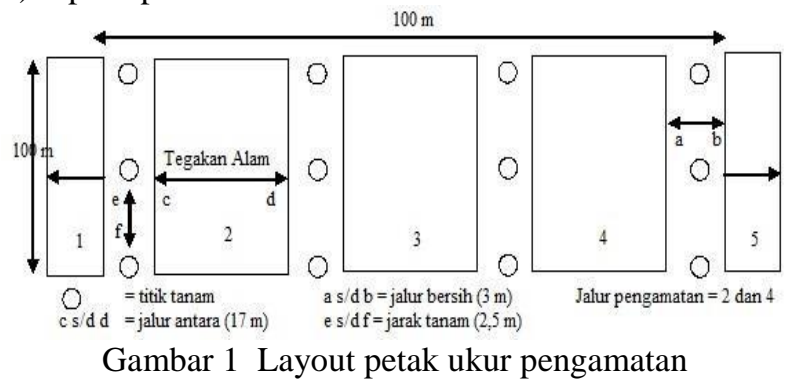

\section{Analisis vegetasi}

Pengambilan data di lapangan dilakukan dengan menggunakan teknik analisis vegetasi metode kombinasi antara metode jalur dan garis petak. Tingkat pohon dilakukan dengan metode jalur sedangkan untuk permudaan dilakukan dengan metode garis berpetak (Indriyanto 2008). Panjang jalur pengamatan yaitu $100 \mathrm{~m}$ dengan lebar $17 \mathrm{~m}$. Setiap jalur dibagi menjadi lima petak pengukuran berukuran $17 \mathrm{~m}$ x 20m. Lima petak masing-masing terbagai menjadi empat subpetak pengamatan yaitu petak $2 \mathrm{~m} \times 2 \mathrm{~m}$ untuk pengamatan tingkat semai, petak $5 \mathrm{~m} \times 5 \mathrm{~m}$ untuk pengamatan tingkat pancang, $10 \mathrm{~m} \times 10 \mathrm{~m}$ untuk pengamatan tingkat tiang dan $17 \mathrm{~m}$ x $20 \mathrm{~m}$ untuk pengamatan tingkat pohon seperti pada Gambar 2. Data yang dikumpulkan dari analisis vegetasi adalah nama dan jumlah jenis pada semua tingkat pertumbuhan serta diameter dan tinggi pada tingkat tiang dan pohon.

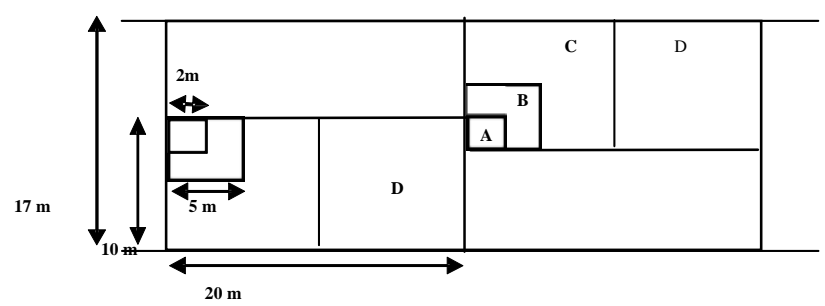

Gambar 2 Desain jalur analisis vegetasi hutan alam

\section{Pengelompokan Data}

Pengelompokan data yang dilakukan yaitu pengelompokan jenis ke dalam kelompok jenis pionir dan klimaks FSG. Pengelompokan tersebut didasarkan pada asumsi bahwa pola dinamika struktur tegakan akan berbeda untuk setiap kelompok jenis. Penelitian ini menekankan pada penggunaan FSG untuk menjelaskan sifat biodiversitas yaitu proses ekosistem. Kriteria FSG dapat dilihat pada Tabel 1.

Tabel 1 Pengelompokan FSG berdasarkan pada ciri-ciri autekologi yang berbeda

\begin{tabular}{|c|c|c|}
\hline Karakteristik & Pionir & Klimaks \\
\hline Persamaan & $\begin{array}{l}\text { Bergantung pada } \\
\text { cahaya, intoleran }\end{array}$ & Toleran \\
\hline Kemunculan & $\begin{array}{l}\text { Awal hutan } \\
\text { sekunder }\end{array}$ & Hutan primer \\
\hline Kelenturan tapak & Tinggi & Rendah \\
\hline Benih & $\begin{array}{l}\text { Kecil, diproduksi } \\
\text { dalam jumlah } \\
\text { besar pertahun }\end{array}$ & $\begin{array}{l}\text { Besar, diproduksi } \\
\text { dalam jumlah } \\
\text { kecil tidak } \\
\text { pertahun }\end{array}$ \\
\hline $\begin{array}{l}\text { Penyebaran } \\
\text { benih }\end{array}$ & Sangat luas & Sempit \\
\hline Viabilitas benih & Panjang & Pendek \\
\hline Dormansi benih & $\begin{array}{l}\text { Sangat sering, } \\
\text { ortodoks }\end{array}$ & $\begin{array}{l}\text { Jarang, } \\
\text { rekasiltran }\end{array}$ \\
\hline $\begin{array}{l}\text { Perkecambahan } \\
\text { benih }\end{array}$ & $\begin{array}{l}\text { Dalam cahaya } \\
\text { penuh di ruang } \\
\text { terbuka }\end{array}$ & $\begin{array}{l}\text { Ternaungi di } \\
\text { bawah kanopi }\end{array}$ \\
\hline $\begin{array}{l}\text { Karakteristik } \\
\text { pertumbuhan }\end{array}$ & $\begin{array}{l}\text { Fast growing } \\
\text { selama fase } \\
\text { belum, puncak } \\
\text { awal dari Current } \\
\text { Annual } \\
\text { Increament } \\
\text { (CAI) dewasa }\end{array}$ & $\begin{array}{l}\text { Tumbuh lambat } \\
\text { selama produksi, } \\
\text { akhir puncak dari } \\
\text { Current Annual } \\
\text { Increament (CAI) }\end{array}$ \\
\hline $\begin{array}{l}\text { Tinggi pohon } \\
\text { akhir }\end{array}$ & $<20 \mathrm{~m}$ & $>30 \mathrm{~m}$ \\
\hline Kerapatan kayu & Tinggi & Bervariasi-tinggi \\
\hline Perkembangan & $\begin{array}{l}\text { Awal mulai fase } \\
\text { belum dewasa, } \\
\text { tidak berumur } \\
\text { panjang ( }<50 \text { thn })\end{array}$ & $\begin{array}{l}\text { Akhir fase, } \\
\text { berumur panjang } \\
(>100 \text { thn) }\end{array}$ \\
\hline
\end{tabular}

Sumber : Pohris 2009

\section{Analisis Data}

\section{Struktur Tegakan}

Struktur tegakan menggambarkan sebaran jenis pohon (N/ha) dengan menggunakan data diameter 
pohon dalam suatu kawasan hutan (Husch 1982). Sebaran kelas diameter yang mendekati kurva J-terbalik menunjukkan bahwa area tersebut mempunyai karakteristik hutan tidak seumur yang seimbang (Pamoengkas 2006).

\section{Komposisi Jenis Permudaan}

Ketersediaan permudaan alam yang cukup dapat menjamin adanya generasi baru untuk regenerasi hutan secara alami. Wayy-Smith (1963) menyatakan bahwa permudaan dianggap cukup memadai bila tersedia 1000 batang/ha cadangan permudaan semai, 240 batang/ha cadangan permudaan tingkat pancang dan 75 batang/ha cadangan permudaan tingkat tiang.

\section{Indeks Nilai Penting (INP)}

Indeks Nilai Penting (INP) digunakan untuk menganalisis dominansi (penguasaan) suatu jenis dalam komunitas tertentu. Rumus matematis perhitungan INP menurut Misra (1980) yaitu:

$$
\begin{aligned}
& \text { Kerapatan }(\mathrm{K})=\frac{\text { jumlah individu suatu jenis }(\mathrm{N})}{\text { luas petak contoh (ha) }} \\
& \text { Kerapatan Relatif }(\mathrm{KR})=\frac{\text { kerapatan suatu jenis (N/ha) }}{\text { kerapatan seluruh jenis }} \times 100 \%
\end{aligned}
$$$$
\text { (N/ha) }
$$

Frekuensi $(F)=\frac{\text { jumlah plot ditemukan suatu jenis }}{\text { jumlah seluruh plot }}$

Frekuensi Relatif $(\mathrm{FR})=\frac{\text { frekuensi suatu jenis }}{\text { frekuensi seluruh jenis }} \times 100 \%$

Dominansi $(D)=\frac{\text { jumlah bidang dasar suatu jenis }\left(\mathrm{m}^{2}\right)}{\text { luas petak contoh }(\text { ha })}$

Dominansi Relatif $(\mathrm{DR})=\frac{\begin{array}{c}\text { dominansi suatu jenis } \\ \left(\mathrm{m}^{2} / \mathrm{ha}\right)\end{array}}{\text { dominansi seluruh jenis }} \times 100 \%$ $\left(\mathrm{m}^{2} / \mathrm{ha}\right)$

\section{Indeks keanekaragaman jenis (H')}

Indeks keanekaragaman jenis adalah parameter yang digunakan untuk mengetahui stabilitas suatu komunitas atau kemampuan suatu komunitas untuk menjaga dirinya tetap stabil dari gangguan terhadap komponenkomponen penyusunnya (Soegianto dalam Indrianto 2008). Analisis Indeks Keanekaragaman Jenis ( $\left.H^{\prime}\right)$ dihitung menggunakan rumus keanekaragaman jenis Shanon (Maguran 1988) sebagai berikut:

$$
\mathrm{H}^{\prime}=-\sum_{i=1}^{s}\left(\frac{n i}{N}\right) \ln \left(\frac{n i}{N}\right)
$$

Ket:

H'= Indeks Keanekaragaman Jenis Shanon

ni $=$ nilai kerapatan jenis ke-i

$\mathrm{N}=$ total kerapatan

Kriteria dalam analisis indeks keanekaragaman jenis yaitu jika nilai $\mathrm{H}^{\prime}<2$ maka nilai keanekaragaman jenisnya termasuk ke dalam kategori rendah, jika nilai 2 $<\mathrm{H}^{\prime}<3$ termasuk ke dalam kategori sedang dan jika nilai H'> 3 termasuk kategori tinggi (Maguran 1988).

\section{Indeks ketidaksamaan komunitas (ID)}

Indeks ketidaksamaan komunitas adalah indeks yang digunakan untuk mengetahui tingkat ketidaksamaan antar komunitas tumbuhan dengan membandingkan komposisi atau struktur komunitasnya. Nilai ID berkisar antara $0-100 \%$, jika nilai ID $=0 \%$ maka kedua komunitas yang dibandingkan akan benar-benar sama dan jika nilai ID $=100 \%$ maka berbeda (Ludwig \& Reynold 1988). Rumus dari IS dan ID sebagai berikut (Indriyanto 2008):

$$
\begin{aligned}
& \text { IS }=\frac{2 W}{a+b} \times 100 \% \\
& I D=100 \%-I S
\end{aligned}
$$

Ket:

IS = indeks kesamaan komunitas

$\mathrm{W}=$ jumlah dari nilai penting yang lebih kecil atau sama dari dua jenis berpasangan yang ditemukan pada dua komunitas

a = total nilai penting dari komunitas $\mathrm{A}$

$\mathrm{b}=$ total nilai penting dari komunitas $\mathrm{B}$

ID $=$ indeks ketidaksamaan komunitas

\section{KONDISI UMUM}

PT. Sarpatim memiliki izin usaha pemanfaatan hasil hutan kayu pada hutan alam (IUPHHK-HA) untuk jangka waktu 45 tahun (periode 5 November 1992 sampai 5 November 2037) seluas 216580 Ha. IUPHHK-HA PT. Sarpatim sesuai dengan SK Menteri Kehutanan Nomor SK.266/MENHUT-II/2004 tanggal 21 Juli 2004. Area IUPHHK-HA PT. Sarpatim termasuk dalam kelompok hutan Sungai Kalek dan Sungai Nahiang. Letak geografis PT. Sarpatim yaitu pada $111^{\circ} 55^{\prime}-112^{\circ} 19^{\prime}$ BT dan $1^{\circ} 12^{\prime}-1^{\circ} 56^{\prime}$ LS, dengan wilayah administrasi pemerintahan terletak di Kabupaten Seruyan, Katingan dan Kotawaringin Timur, Provinsi Kalimantan Tengah.

Kondisi penutupan lahan PT. Sarpatim berdasarkan Citra Landsat 2012 yaitu 164179 Ha hutan sekunder (LOA), $30611 \mathrm{Ha}$ area tidak berhutan dan 21790 ha tertutup awan. Hasil interpretasi peta topografi area kerja PT. Sarpatim bervariasi dari datar sampai berbukit dengan ketinggian berkisar 18-944 mdpl. Jenis tanah yang mendominasi area PT. Sarpatim adalah Dystropepts seluas $61 \%$ dari luas total area dan tropodults seluas 39\%. Tipe iklim berdasarkan Schmidt \& Ferguson area PT. Sarpatim termasuk tipe A dengan curah hujan $3.086 \mathrm{~mm}$ per tahun dan hari hujan selama 145 hari per tahun. Curah hujan tertinggi terjadi pada bulan Oktober sampai Januari dan curah hujan terendah terjadi pada bulan Juli sampai September. Kelembaban rata-rata berkisar antara 38.3-85.6\%. Secara hidrologi PT. Sarpatim memiliki tiga Daerah Aliran Sungai (DAS) yaitu DAS Seruyan, DAS Mentaya dan DAS Mentubar.

Jumlah jenis tumbuhan yang ada di area IUPHHKHA PT. Sarpatim yaitu 386 jenis dari 50 suku atau famili yang terdiri dari 108 jenis Dipterocarpaceae, 39 jenis Euphorbiaceae dll. Jenis tumbuhan yang bernilai rentan (vulnerable) sebanyak 86 jenis, jenis kritis 
(critical endangered) sebanyak 36 jenis, 14 jenis Dipterocarpaceae yang termasuk dilindungi pemerintah dan 10 jenis endemik Indonesia dari 38 jenis yang ditemukan.

\section{HASIL DAN PEMBAHASAN}

\section{Komposisi Jenis Functional Species Group}

Umur, komposisi, struktur dan tempat tumbuh atau geografi dapat membedakan kondisi suatu tegakan hutan (Baker et al. 1987). Analisis mengenai kerapatan dan kontribusi jenis menggambarkan komposisi jenis suatu tegakan dan analisis sebaran kelas diameter menggambarkan struktur tegakan. Komposisi jenis penyusun tegakan dikelompokkan berdasarkan pengelompokan FSG dengan mengelompokan jenis yang termasuk kelompok jenis pionir dan kelompok jenis klimaks. Pengelompokan berdasarkan FSG bertujuan untuk membantu dalam menjelaskan sifatsifat biodiversitas seperti kualitas habitat dan proses ekosistem (Pohris 2009). Selain itu dengan mengetahui komposisi jenis dapat mengetahui keseimbangan komunitas suatu hutan (Muhdi 2009). Komposisi jenis penyusun tegakan pionir dan klimaks ditampilkan pada Gambar 3.

Pengelompokan jenis berdasarkan FSG pada seluruh area pengamatan ditemukan 59 jenis pionir dan 99 jenis klimaks. Gambar 3 menunjukkan jumlah jenis pada seluruh tingkat pertumbuhan yang tergolong kelompok jenis pionir maupun kelompok jenis klimaks. Jumlah jenis tertinggi untuk tingkat pohon yang tergolong kelompok jenis pionir maupun klimaks berada pada KPPN sebanyak 29 jenis pionir dan 47 jenis klimaks. Area bekas tebangan memiliki jumlah jenis untuk kelompok jenis pionir maupun klimaks yang beragam. Hal ini diduga karena adanya perbedaan intensitas penebangan pada masing-masing lokasi dan proses suksesi dengan tingkat kerusakan yang berbeda-beda pada setiap area. Menurut Kartawinata (1975) dalam Utami (2007) kehadiran suatu jenis pada hutan bekas tebangan dipengaruhi oleh besarnya kerusakan akibat penebangan dan pembungaan sehingga regenerasi tidak dapat berlangsung dengan baik.

Tabel 2 menunjukkan kerapatan dan kontribusi jenis pada tingkat pohon. Kelompok jenis klimaks untuk seluruh petak pengamatan memiliki kerapatan yang lebih tinggi dibandingkan dengan kelompok jenis pionir. Sebagai contoh pada LOA 1 kelompok jenis klimaks memiliki kerapatan sebesar 105 (N/ha) dan kontribusi jenis sebesar $67.2 \%$ yang jumlahnya lebih besar dibandingkan kerapatan kelompok jenis pionir yaitu sebesar 51.25 (N/ha) dan kontribusi jenis sebesar
$32.8 \%$. Total kerapatan pada area hutan tidak terganggu atau KPPN lebih besar dibandingkan seluruh LOA. Total kerapatan untuk kelompok jenis klimaks mengalami penurunan mengikuti tahun area tebangan terdekat kecuali pada LOA 5. Sedangkan untuk kelompok jenis pionir menunjukkan kerapatan yang bervariasi.

Tabel 2 Kerapatan dan kontribusi jenis pada petak pengamatan pada tingkat pohon

\begin{tabular}{|c|c|c|c|c|c|}
\hline \multirow{2}{*}{ Tegakan } & \multicolumn{2}{|c|}{ Kerapatan (N/ha) } & \multirow[t]{2}{*}{ Total } & \multicolumn{2}{|c|}{$\begin{array}{c}\text { Kontribusi jenis } \\
(\%)\end{array}$} \\
\hline & Pionir & Klimaks & & Pionir & Klimaks \\
\hline KPPN & 148.75 & 182.50 & 331.25 & 44.91 & 55.09 \\
\hline LOA 9 & 45.00 & 137.50 & 182.50 & 24.66 & 75.34 \\
\hline LOA 7 & 52.50 & 137.50 & 190.00 & 27.63 & 72.37 \\
\hline LOA5 & 28.75 & 155.00 & 183.75 & 15.65 & 84.35 \\
\hline LOA 3 & 46.25 & 126.25 & 172.50 & 26.81 & 73.19 \\
\hline LOA 1 & 51.25 & 105.00 & 156.25 & 32.80 & 67.20 \\
\hline
\end{tabular}

Tabel 3 Kerapatan dan kontribusi jenis pada petak pengamatan pada tingkat tiang

\begin{tabular}{|c|c|c|c|c|c|}
\hline \multirow[t]{2}{*}{ Tegakan } & \multicolumn{2}{|c|}{ Kerapatan (N/ha) } & \multirow[t]{2}{*}{ Total } & \multicolumn{2}{|c|}{$\begin{array}{c}\text { Kontribusi jenis } \\
(\%)\end{array}$} \\
\hline & Pionir & Klimaks & & Pionir & Klimaks \\
\hline KPPN & 225 & 325 & 550 & 40.91 & 59.09 \\
\hline LOA 9 & 200 & 200 & 400 & 50.00 & 50.00 \\
\hline LOA 7 & 140 & 305 & 445 & 31.46 & 68.54 \\
\hline LOA5 & 60 & 165 & 225 & 26.67 & 73.33 \\
\hline LOA 3 & 130 & 275 & 405 & 32.10 & 67.90 \\
\hline LOA 1 & 95 & 85 & 180 & 52.78 & 47.22 \\
\hline
\end{tabular}

Kerapatan dan kontribusi jenis untuk tingkat tiang, kelompok jenis klimaks memiliki kerapatan terbesar dibandingkan kelompok jenis pionir yang ditunjukkan pada Tabel 3. LOA 1 menunjukkan kelompok jenis pionir memiliki kerapatan yang lebih banyak dibandingkan kelompok jenis klimaks yaitu $95 \mathrm{~N} / \mathrm{ha}$. Hal ini diduga karena pada lokasi tersebut baru saja di lakukan pemanenan sehingga kemunculan kelompok jenis klimaks lebih sedikit dibandingkan kelompok jenis pionir.

Kerapatan dan kontribusi jenis permudaan hutan yaitu pada tingkat semai dan pancang dapat dilihat pada Tabel 4 dan Tabel 5. Kerapatan dan kontirbusi jenis untuk tingkat semai maupun pancang pada kelompok jenis klimaks secara umum memiliki jumlah tertinggi. Kecuali pada LOA 9 dan LOA 3 untuk tingkat pancang. Kerapatan dan kontribusi jenis permudaan juga digunakan untuk mengetahui jumlah ketersediaan permudaan dan menjamin adanya regenerasi baru pada suatu komunitas. 


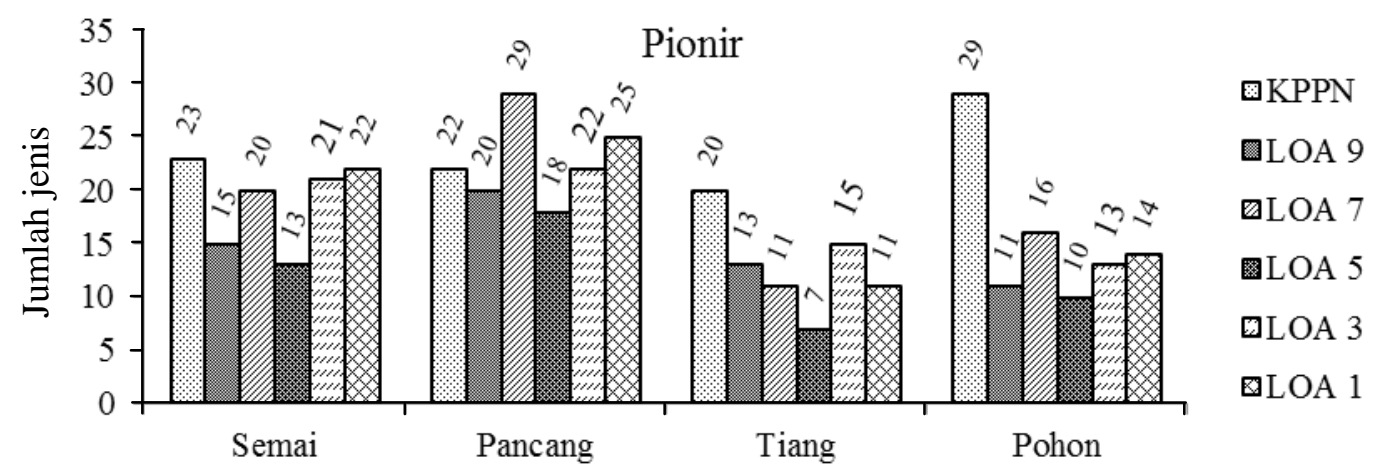

(a)

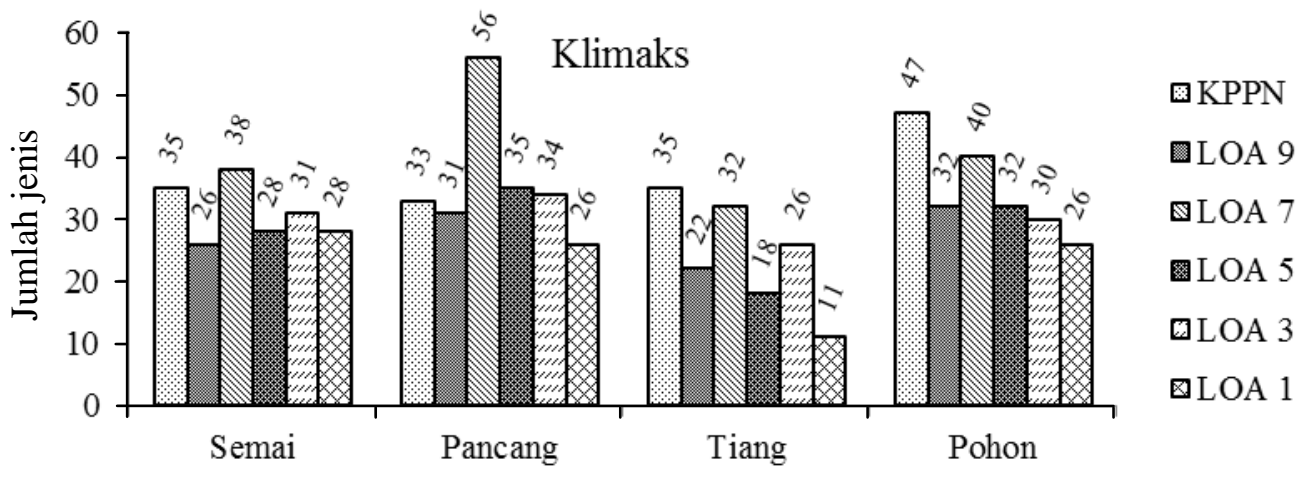

(b)

Gambar 3 Jumlah jenis (a) pionir dan (b) klimaks di seluruh petak pengamatan

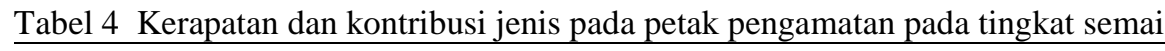

\begin{tabular}{|c|c|c|c|c|c|}
\hline \multirow{2}{*}{ Tegakan } & \multicolumn{2}{|c|}{ Kerapatan (N/ha) } & \multirow{2}{*}{ Total } & \multicolumn{2}{|c|}{ Kontribusi jenis (\%) } \\
\hline & Pionir & Klimaks & & Pionir & Klimaks \\
\hline KPPN & 17750 & 22875 & 40625 & 43.69 & 56.31 \\
\hline LOA 9 & 12375 & 22250 & 34625 & 35.74 & 64.26 \\
\hline LOA 7 & 11875 & 17625 & 29500 & 40.25 & 59.75 \\
\hline LOA5 & 4625 & 23125 & 27750 & 16.67 & 83.33 \\
\hline LOA 3 & 15750 & 20875 & 36625 & 43.00 & 57.00 \\
\hline LOA 1 & 13750 & 17625 & 31375 & 43.82 & 56.18 \\
\hline
\end{tabular}

Tabel 5 Kerapatan dan kontribusi jenis pada petak pengamatan pada tingkat pancang

\begin{tabular}{|c|c|c|c|c|c|}
\hline \multirow{2}{*}{ Tegakan } & \multicolumn{2}{|c|}{ Kerapatan (N/ha) } & \multirow{2}{*}{ Total } & \multicolumn{2}{|c|}{ Kontribusi jenis (\%) } \\
\hline & Pionir & Klimaks & & Pionir & Klimaks \\
\hline KPPN & 1360 & 1460 & 2820 & 48.23 & 51.77 \\
\hline LOA 9 & 2940 & 2880 & 5820 & 50.52 & 49.48 \\
\hline LOA 7 & 2380 & 3160 & 5540 & 42.96 & 57.04 \\
\hline LOA5 & 2060 & 2360 & 4420 & 46.61 & 53.39 \\
\hline LOA 3 & 2720 & 2200 & 4920 & 55.28 & 44.72 \\
\hline LOA 1 & 1500 & 1520 & 3020 & 49.67 & 50.33 \\
\hline
\end{tabular}

Tingkat semai, pancang dan tiang memiliki ketersediaan di alam yang cukup. Tingkat semai memiliki jumlah kerapatan jenis total yang berkisar 27 750 - 40625 N/ha. Hal ini sesuai dengan Wayy-Smith (1963) yang menyatakan bahwa permudaan dianggap cukup memadai bila tersedia $1000 \mathrm{~N} / \mathrm{ha}$ cadangan permudaan semai. Tabel 5 menunjukkan cadangan permudaan tingkat pancang yang melebihi 240 N/ha. Selain itu cadangan permudaan tingkat tiang juga melebihi $75 \mathrm{~N} /$ ha yang dapat dilihat pada Tabel 3. Hal ini menunjukkan bahwa secara umum area hutan bekas tebangan yang dikelola dengan sistem silvikultur TPTJ memiliki kesempatan dalam penambahan pohon inti. Pamoengkas (2006) menyatakan pertumbuhan tiang dapat menambah jumlah pohon inti dalam jumlah yang banyak.

\section{Struktur Tegakan}

Gambar 4 menunjukkan bahwa kelompok jenis klimaks mendominasi dibandingkan kelompok jenis pionir kecuali pada LOA 9 dan LOA 1. Hal ini dapat disebabkan oleh adanya kegiatan pemeliharaan yaitu pelebaran jalur untuk mendukung pertumbuhan tanaman jalur pada LOA 9 dan umur penebangan yang baru 1 tahun pada LOA 1, sehingga mengakibatkan keterbukaan tajuk yang memicu tumbuhnya kelompok jenis pionir.

Distribusi struktur tegakan untuk kelompok jenis pionir dan klimaks untuk seluruh petak pengamatan cenderung membentuk kurva $\mathrm{J}$ terbalik. Hal ini 
menunjukkan bahwa area hutan bekas tebangan yang dikelola dengan sistem silvikutur TPTJ memiliki kondisi hutan area hutan bekas tebangan tidak seumur yang masih seimbang. Hutan alam memiliki kerapatan pohon yang tinggi pada kelas diameter kecil dan menurun pada kelas diameter yang lebih besar (Richard 1964). Wahjono (2007) menyatakan bahwa struktur tegakan hutan normal yang membentuk $\mathrm{J}$ terbalik menunjukkan kondisi tegakan setelah penebangan masih cukup baik sebagai penyusun tegakan pada rotasi berikutnya.

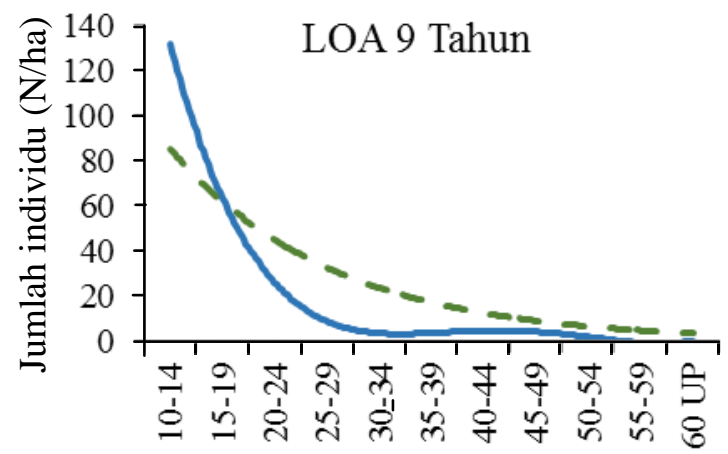

Kelas diameter (cm)

Kelompok jenis pionir

- - Kelompok jenis klimaks

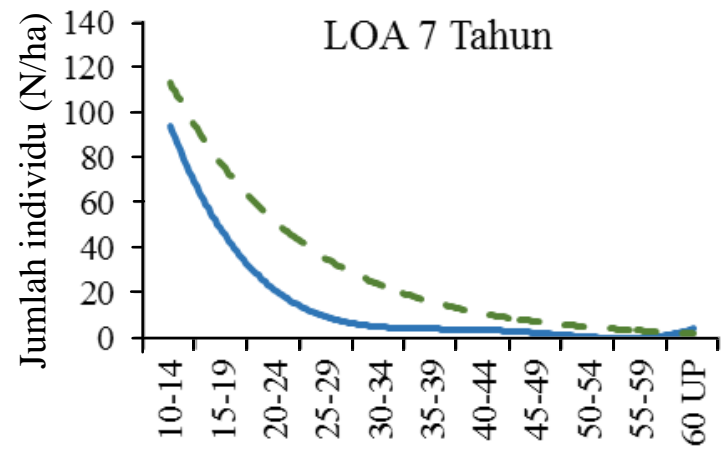

Kelas diameter (cm)

Kelompok jenis pionir

- - Kelompok jenis klimaks

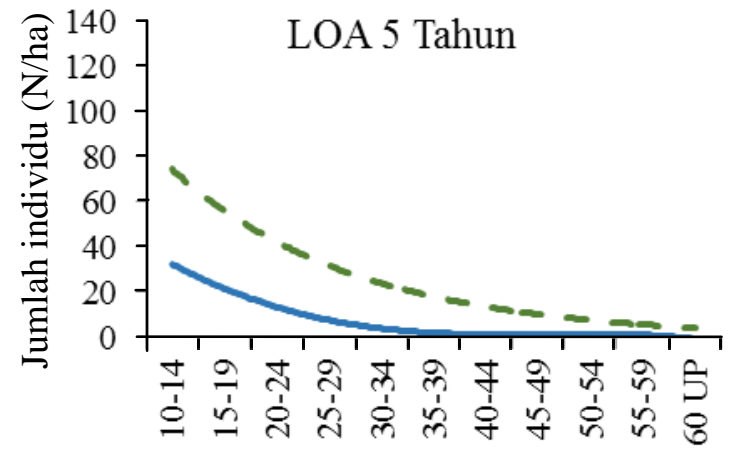

Kelas diameter (cm)

Kelompok jenis pionir

- Kelompok jenis klimaks

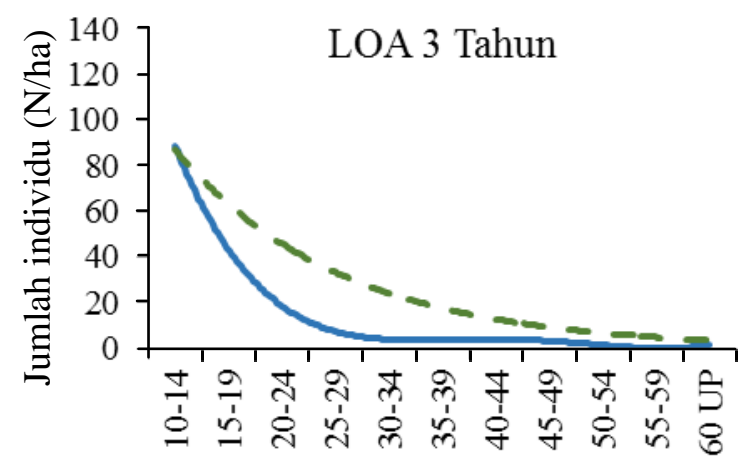

Kelas diameter $(\mathrm{cm})$

- Kelompok jenis pionir

- Kelompok jenis klimaks

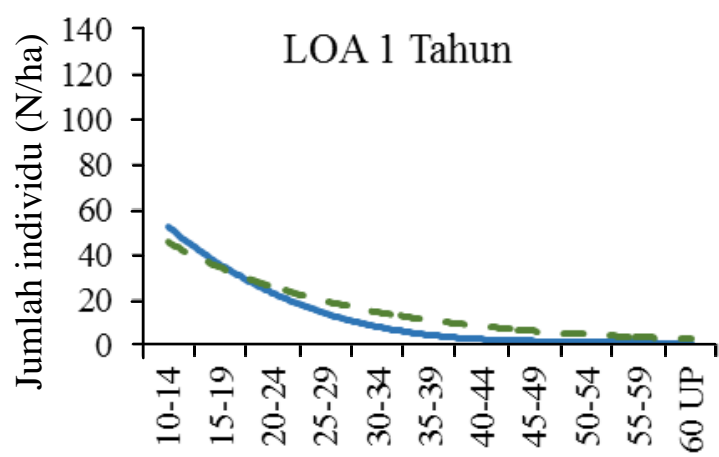

Kelas diameter $(\mathrm{cm})$

Kelompok jenis pionir

- Kelompok jenis klimaks

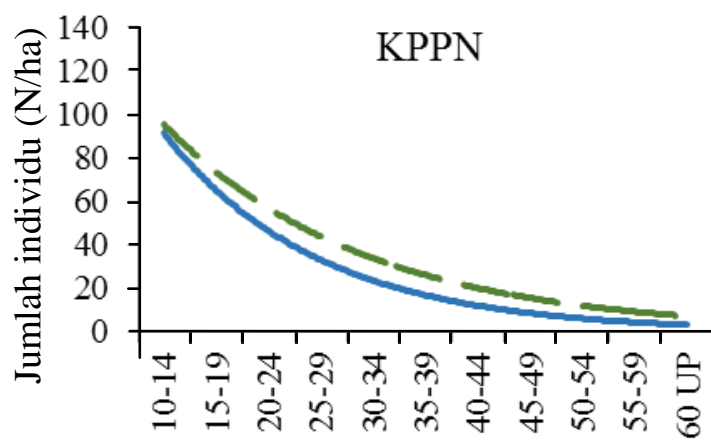

Kelas diameter (cm)

Kelompok jenis pionir
- - Kelompok jenis klimaks

Gambar 4 Distribusi struktur tegakan untuk kelompok jenis pionir dan klimaks pada petak pengamatan

\section{Indeks Keanekaragaman Jenis}

Tabel 6 menunjukkan nilai indeks keanekaragaman jenis untuk strata pohon dan permudaan pada semua petak pengamatan. Strata pohon ataupun permudaan pada semua petak pengamatan memiliki keanekaragaman jenis yang tergolong tinggi karena indeks keanekaragaman pada masing-masing lokasi memiliki nilai $>3$. 
Tabel 6 Indeks keanekaragaman jenis pada petak pengamatan

\begin{tabular}{lcccccc}
\hline Strata & \multicolumn{5}{c}{ Indeks keanekaragaman Jenis (H') } \\
\cline { 2 - 7 } Pertumbuhan & KPPN & LOA & LOA & LOA & LOA & LOA 1 \\
\hline Semai & 3.5 & 3.2 & 3.7 & 3.1 & 3.2 & 3.4 \\
Pancang & 3.8 & 3.3 & 4.1 & 3.5 & 3.7 & 3.6 \\
Tiang & 3.8 & 3.2 & 3.5 & 3.0 & 3.5 & 3.0 \\
Pohon & 4.0 & 3.5 & 3.7 & 3.4 & 3.4 & 3.3 \\
\hline
\end{tabular}

Sesuai dengan penelitian serupa di lokasi yang sama oleh Utami (2007) yang menyatakan bahwa keragaman di lokasi penelitian cukup tinggi. Hal ini dapat diartikan bahwa komposisi jenis pada semua strata sangat melimpah, beranekaragam atau heterogen dan memiliki stabilitas komunitas yang tinggi. Stabilitas komunitas yaitu kemampuan suatu komunitas menjaga kestabilannya walaupun adanya gangguan terhadap komponen-komponen penyusunnya yang dapat dilihat dari keanekaragaman jenis pada suatu komunitas (Indriyanto 2008).

\section{Indeks Nilai Penting}

Analisis indeks nilai penting (INP) digunakan untuk mengetahui jenis-jenis yang mendominasi pada petak pengamatan. Smith (1977) dalam Mawazin (2013) menyatakan bahwa jenis dominan adalah jenis yang dapat memanfaatkan lingkungannya secara efisien dari jenis lain dalam tempat yang sama. Jenis dominan merupakan jenis yang mempunyai nilai INP tertinggi di dalam suatu vegetasi hutan (Kusmana 1997). Suatu jenis dapat dikatakan berperan jika nilai INP untuk tingkat semai dan pancang $\geq 10 \%$ dan untuk tingkat tiang dan pohon memiliki nilai INP $\geq 15 \%$.

Tabel 7 menunjukkan bahwa pada tingkat pohon didominansi oleh kelompok jenis klimaks Dipterocarpaceae pada seluruh petak pengamatan. Jenis yang mendominasi dengan merata yaitu Shorea parvifolia dengan nilai mencapai $40.4 \%$ dan terdapat pada lima dari enam petak pengamatan, sedangkan Shorea laevis dengan nilai mencapai $36.0 \%$ yang terdapat pada tiga dari enam petak pengamatan. Jenis meranti merah merupakan jenis utama yang digunakan sebagai bahan baku kayu lapis. Tabel 8 menunjukkan bahwa 14 jenis klimaks dan 10 jenis pionir mendominasi pada tingkat tiang. Jenis paling mendominasi adalah jenis Syzygium borneense dari kelompok jenis klimaks dengan INP sebesar $48.6 \%$ sedangkan 2 INP terbesar lainnya yaitu Macaranga hypoleuca dan Symplocos cochinchinensis dari kelompok jenis pionir dengan INP sebesar $40.2 \%$ dan $30.6 \%$. Secara umum masing-masing jenis yang ditemukan tidak mendominasi merata atau hanya mendominasi pada satu sampai tiga area pengamatan saja.

Tabel 7 Indeks nilai penting di atas $15 \%$ pada tingkat pohon pada petak pengamatan

\begin{tabular}{|c|c|c|c|c|c|c|c|}
\hline \multirow{2}{*}{ Nama Jenis } & \multirow{2}{*}{ Grup } & \multicolumn{6}{|c|}{ Indeks Nilai Penting } \\
\hline & & KPPN & LOA 9 & LOA 7 & LOA 5 & LOA 3 & LOA 1 \\
\hline Castanopsis costata & $\mathrm{K}$ & - & - & 22.3 & 22.8 & - & - \\
\hline Cephalomappa mallotocarpa & $\mathrm{P}$ & - & - & - & - & - & 23.9 \\
\hline Dacryodes rugosa & $\mathrm{P}$ & - & - & - & - & - & 22.7 \\
\hline Dipterocarpus caudiferus. & K & - & - & - & - & 17.2 & - \\
\hline Hopea dryobalanoides & K & - & 16.8 & - & - & - & - \\
\hline Koompassia malaccensis & K & - & - & - & - & - & 15.3 \\
\hline Pternandra caerulescens & $P$ & - & - & 16.0 & - & - & - \\
\hline Scorodocorpus borneensis & $\mathrm{K}$ & - & - & - & - & - & 19.0 \\
\hline Shorea laevis & $\mathrm{K}$ & - & 36.0 & - & 16.7 & 22.5 & - \\
\hline Shorea parvifolia & $\mathrm{K}$ & 18.4 & - & 18.2 & 34.3 & 40.4 & 43.1 \\
\hline Shorea smithiana & $\mathrm{K}$ & - & 17.4 & - & - & - & - \\
\hline Symplocos cochinchinensis & $\mathrm{P}$ & - & - & - & - & - & - \\
\hline Syzygium borneense & $\mathrm{K}$ & - & - & - & 19.4 & 16.7 & 21.2 \\
\hline
\end{tabular}

Ket : K : Klimaks ; P : Pionir

Tabel 8 Indeks nilai penting di atas $15 \%$ pada permudaan pohon (tiang) pada petak pengamatan

\begin{tabular}{|c|c|c|c|c|c|c|c|}
\hline \multirow{2}{*}{ Nama Jenis } & \multirow{2}{*}{ Grup } & \multicolumn{6}{|c|}{ Indeks Nilai Penting } \\
\hline & & KPPN & LOA 9 & LOA 7 & LOA 5 & LOA 3 & LOA 1 \\
\hline Antidesma coriaceum & $\mathrm{P}$ & 15.2 & - & - & - & - & - \\
\hline Aporosa sphaeridophora & $\mathrm{P}$ & - & - & - & - & - & 28.3 \\
\hline Castanopsis costata & $\mathrm{K}$ & - & - & 18.3 & - & - & - \\
\hline Chisocheton sp & $\mathrm{P}$ & - & 16.6 & - & - & - & - \\
\hline Dacryodes rugosa & $\mathrm{P}$ & - & 19.0 & - & - & - & 25.3 \\
\hline Dehaasia caesia & $\mathrm{P}$ & - & - & - & - & - & 24.6 \\
\hline Diospyros rostrata & $\mathrm{K}$ & - & - & - & 18.8 & - & - \\
\hline Hopea dryobalanoides & $\mathrm{K}$ & - & 23.4 & - & 23.8 & - & 16.0 \\
\hline Ilex accuminata & $\mathrm{K}$ & - & - & - & - & 15.3 & - \\
\hline Litsea machilifolia & $\mathrm{K}$ & - & - & - & - & 21.3 & - \\
\hline Macaranga gigantea & $\mathrm{P}$ & - & - & 22.2 & - & - & - \\
\hline Macaranga hypoleuca & $\mathrm{P}$ & - & 40.2 & - & - & - & - \\
\hline Paranephelium xestophyllum & $\mathrm{K}$ & 16.3 & - & - & - & - & - \\
\hline Polyalthia xanthopetala & $\mathrm{P}$ & - & - & - & 15.9 & - & - \\
\hline Pternandra caerulescens & $\mathrm{P}$ & - & - & - & - & - & 16.8 \\
\hline Scorodocorpus borneensis & $\mathrm{K}$ & - & - & - & - & - & 16.6 \\
\hline
\end{tabular}




\begin{tabular}{lccccccc}
\hline \multicolumn{1}{c}{ Nama Jenis } & \multirow{2}{*}{ Grup } & \multicolumn{5}{c}{ Indeks Nilai Penting } \\
\cline { 3 - 7 } & & KPPN & LOA 9 & LOA 7 & LOA 5 & LOA 3 & LOA 1 \\
\hline Shorea macrophylla & $\mathrm{K}$ & - & - & - & 15.4 & - & - \\
Shorea parvifolia & $\mathrm{K}$ & - & - & - & - & - & 20.1 \\
Shorea pauciflora & $\mathrm{K}$ & - & - & 16.5 & - & - & - \\
Shorea smithiana & $\mathrm{K}$ & - & 19.8 & - & - & - & - \\
Strombosia ceylanica & $\mathrm{K}$ & - & - & - & 15.0 & - & - \\
Symplocos cochinchinensis & $\mathrm{P}$ & - & - & - & 30.6 & - & 17.0 \\
Syzygium borneense & $\mathrm{K}$ & - & - & - & 48.6 & 27.9 & 25.1 \\
Syzygium sp. & $\mathrm{K}$ & - & - & 21.4 & - & - & - \\
\hline
\end{tabular}

Ket : K : Klimaks ; P : Pionir

Tabel 9 Indeks nilai penting di atas $10 \%$ pada permudaan pohon (semai) pada petak pengamatan

\begin{tabular}{lccccccc}
\multicolumn{2}{c}{ Nama Jenis } & \multirow{2}{*}{ Grup } & \multicolumn{7}{c}{ Indeks Nilai Penting } \\
\cline { 3 - 8 } & & KPPN & LOA 9 & LOA 7 & LOA 5 & LOA 3 & LOA 1 \\
\hline Antidesma coriaceum & $\mathrm{P}$ & - & 12.7 & - & - & - & - \\
Chisocheton sp & $\mathrm{P}$ & - & 21.0 & - & - & - & - \\
Diospyros rostrata & $\mathrm{K}$ & - & - & - & 13.8 & - & - \\
Gluta wallichii & $\mathrm{K}$ & - & 18.5 & - & - & - & - \\
Hopea dryobalanoides & $\mathrm{K}$ & - & 14.8 & - & - & - & - \\
Koompassia malaccensis & $\mathrm{K}$ & - & - & - & 10.0 & - & - \\
Madhuca erythrophylla & $\mathrm{K}$ & - & - & - & - & - & 13.0 \\
Memecylon edule & $\mathrm{P}$ & - & - & - & - & - & 13.6 \\
Pternandra caerulescens & $\mathrm{P}$ & - & - & 11.7 & - & 16.2 & - \\
Shorea acuminatissima & $\mathrm{K}$ & 20.1 & - & - & - & - & - \\
Shorea laevis & $\mathrm{K}$ & - & 14.2 & - & - & - & - \\
Shorea parvifolia & $\mathrm{K}$ & 10.5 & - & - & - & 10.5 & 20.4 \\
Shorea pauciflora & $\mathrm{K}$ & - & - & - & 17.8 & - & - \\
Shorea smithiana & $\mathrm{K}$ & - & - & - & - & 11.5 & - \\
Syzygium borneense & $\mathrm{K}$ & - & - & - & 13.7 & 26.2 & - \\
Trigonostemon sp & $\mathrm{P}$ & - & - & 14.8 & - & - & - \\
Vatica nitens & $\mathrm{K}$ & - & - & - & 23.2 & - \\
\hline Ket: K KIImaks $;$ P: & & & & & & & - \\
\hline
\end{tabular}

Ket: K : Klimaks ; P : Pionir

Tabel 10 Indeks nilai penting di atas $10 \%$ pada permudaan pohon (pancang) pada petak pengamatan

\begin{tabular}{llcccccc}
\hline \multicolumn{2}{c}{ Nama Jenis } & \multirow{2}{*}{ Grup } & \multicolumn{5}{c}{ Indeks Nilai Penting } \\
\cline { 3 - 8 } & & KPPN & LOA 9 & LOA 7 & LOA 5 & LOA 3 & LOA 1 \\
\hline Antidesma coriaceum & $\mathrm{P}$ & - & 12.3 & 10.4 & 12.0 & - & 11.2 \\
Gluta wallichii & $\mathrm{K}$ & - & 13.3 & - & - & - & - \\
Hydnocarpus kunstleri & $\mathrm{K}$ & - & - & 11.7 & - & - & - \\
Macaranga hypoleuca & $\mathrm{P}$ & - & - & - & 15.8 & - & - \\
Madhuca erythrophylla & $\mathrm{K}$ & - & - & - & - & - & 11.9 \\
Paracroton pendulus & $\mathrm{P}$ & - & - & - & - & 10.1 & - \\
Polyalthia xanthopetala & $\mathrm{P}$ & - & - & - & 12.4 & - & - \\
Shorea laevis & $\mathrm{K}$ & - & 13.1 & - & 10.8 & - & - \\
Shorea parvifolia & $\mathrm{K}$ & - & - & - & - & - & 14.5 \\
Symplocos cochinchinensis & $\mathrm{P}$ & - & 25.6 & - & - & - & \\
\hline
\end{tabular}

Ket : K : Klimaks ; P : Pionir

Tabel 11 Indeks ketidaksamaan pada seluruh petak pengamatan dan tingkat pertumbuhan

\begin{tabular}{lllllll}
\hline ID & Lokasi & LOA 9 & LOA 7 & LOA 5 & LOA 3 & LOA 1 \\
\hline Semai & KPPN & 74.3 & 70.8 & 64.9 & 61.8 & 65.2 \\
& LOA 9 & & 61.3 & 66.4 & 68.1 & 76.0 \\
& LOA 7 & & & 69.5 & 64.3 & 77.3 \\
Pancang & LOA 5 & & & & 60.9 & 73.5 \\
& LOA 3 & & & & 63.8 \\
& KPPN & 74.0 & 63.1 & 69.9 & 63.7 & 58.6 \\
& LOA 9 & & 62.5 & 51.3 & 53.7 & 63.3 \\
Tiang & LOA 7 & & & 66.3 & 58.5 & 57.3 \\
& LOA 5 & & & & 57.9 & 61.0 \\
& LOA 3 & & & & 60.9 \\
& KPPN & 69.8 & 62.7 & 69.5 & 66.4 & 63.2 \\
& LOA 9 & & 67.1 & 68.2 & 68.2 & 70.1 \\
& LOA 7 & & & 75.4 & 69.3 & 76.9 \\
\hline
\end{tabular}




\begin{tabular}{lllllll}
\hline ID & Lokasi & LOA 9 & LOA 7 & LOA 5 & LOA 3 & LOA 1 \\
\hline \multirow{3}{*}{ Pohon } & LOA 3 & & & & & 57.4 \\
& KPPN & 58.7 & 54.4 & 55.4 & 60.9 & 65.2 \\
& LOA 9 & & 56.1 & 49.4 & 55.2 & 69.2 \\
& LOA 7 & & & 50.9 & 56.2 & 72.6 \\
& LOA 5 & & & & 39.7 & 56.7 \\
& LOA 3 & & & & & 54.1 \\
\hline
\end{tabular}

Dominansi jenis untuk permudaan tingkat semai dan pancang dapat dilihat pada Tabel 9 dan 10. Tingkat semai didominasi oleh kelompok jenis klimaks dengan ditemukannya 12 jenis klimaks dari 17 jenis yang paling mendominasi. Tiga INP tertinggi yaitu 26.2\% untuk jenis Syzygium borneense dan 23.2\% untuk Vatica nitens dari kelompok jenis klimaks dan $21.0 \%$ untuk Chisocheton $s p$ untuk kelompok jenis pionir. Secara umum masing-masing jenis yang ditemukan tidak mendominasi merata pada tiap area pengamatan atau hanya mendominasi di satu sampai tiga area pengamatan saja. Dominansi untuk tingkat pancang yaitu dari kelompok jenis pionir Symplocos chocinchinensis (25.6\%) dan Macaranga hypoleuca (15.8\%). Jenis Antidesma coriaceum dari kelompok jenis pionir paling mendominasi di empat dari enam lokasi pengamatan. Namun untuk KPPN tidak ditemukan dominansi tingkat pancang. Hal ini dapat disebabkan oleh banyaknya jumlah jenis yang ditemukan pada area tersebut (55 jenis).

\section{Indeks Ketidasamaan Komunitas}

Penilaian tingkat ketidaksamaan jenis komunitas dilakukan pada tingkat pohon dan permudaannya dengan membandingkan masing-masing petak pengamatan. Nilai indeks ketidaksamaan komunitas pada tingkat pohon dan permudaannya dapat dilihat pada Tabel 11.

Komunitas pohon dan permudaan antar petak yang dibandingkan cenderung memiliki komunitas pohon yang berbeda yang terlihat dari nilai ID yang lebih besar dari 50\%. Sesuai dengan penelitian Andini (2013) di lokasi yang sama bahwa pada komunitas pohon hubungan kesamaan komunitas antarpetak pengamatan relatif berbeda. Hal ini sesuai dengan pernyataan Soerianagara \& Indrawan (1998), bahwa hutan hujan tropika memiliki keragaman yang sangat tinggi pada tingkat spesies yang menyebabkan penyusun komunitas juga beragam dan kompleks.

Komunitas pohon pada LOA 5 yang dibandingkan dengan LOA 9 dan LOA 3 yang dibandingkan dengan LOA 7 memiliki komunitas pohon yang tidak jauh berbeda atau relatif sama dengan nilai ID kurang dari $50 \%$, hal ini dikarenakan letak petak pengamatan yang berdekatan yaitu petak 73 AH pada LOA 5 dan petak 76AF dan 76 AG pada LOA 9, sedangkan LOA 3 dan LOA 7 petak yang berdekatan yaitu $73 \mathrm{AH}$ dan $72 \mathrm{AH}$. Kondisi tersebut memungkinkan adanya kesamaan iklim mikro yang dapat mendukung pertumbuhan tanaman dengan jenis yang sama diantara kedua petak pengamatan dan adanya kemungkinan penyebaran benih yang dapat menjangkau kedua petak pengamatan yang berdekatan tersebut. Whitten (1987) dalam Mansyur (2003) menyatakan bahwa beberapa faktor seperti kimia tanah, air tanah, iklim jarak antara permukaan laut (mdpl) dan jarak dari daerah yang memiliki kondisi serupa dapat memengaruhi pertumbuhan vegetasi tertentu pada lokasi tertentu.

\section{SIMPULAN DAN SARAN}

\section{Simpulan}

Kelompok jenis klimaks pada seluruh petak pengamatan secara umum memiliki proporsi lebih besar dibandingkan kelompok jenis pionir, yaitu sebanyak 59 jenis pionir dan 99 jenis klimaks. Pemulihan komposisi vegetasi dilihat dari sebaran kelas diameter pada seluruh petak pengamatan menunjukkan bahwa pada area bekas tebangan yang dikelola menggunakan sistem silvikultur TPTJ memiliki karakteristik hutan tidak seumur yang seimbang.

\section{Saran}

Perlu adanya pengayaan data base mengenai jenis tumbuhan yang terdapat di area konsesi perusahaan untuk mendukung kegiatan penelitian maupun kegiatan operasional perusahaan.

\section{DAFTAR PUSTAKA}

Baker FS, Daniel T dan Helms JA. 1987. Principle of Silviculture (Prinsip-prinsip Silvikultur). Terjemahan oleh D Marsono. Yogyakarta (ID): Gadjah Mada University Press.

Gitay H, Noble IR. 1997. What are functional types and how should we seek them? Plant Functional Types: Their Relevance do Ecosystem Properties and Global Change. Cambridge (US): Cambridge University Press.

Husch B. 1963. Forest mensuration and statistics. New York (US): The Ronald Press Co.

Indriyanto. 2008. Ekologi Hutan. Jakarta (ID): Bumi Aksara.

Kusmana C.1997. Metode Survei Vegetasi. Bogor (ID) : Institut Pertanian Bogor.

Ludwig JA, Reynolds JF. 1988. Statistical Ecology, a Primer on Methods and Computing. New York (US): John Willey and Sons.

Magurran AE. 1988. Measuring Biological Diversity. United Kingdom (GB): TJ International, Padstow, Corbwall.

Mansyur M. 2003. Analisis vegetasi hutan di Desa Sawa dan Desa Kadawaa Taman Nasional Lore Lindu, Sulawesi Tengah. Jurnal Teknik Lingkungan. 4(1):1-7. 
Mueller-Dombois D, Ellenberg H. 1974. Aims and Methods of Vegetation Ecology. Canada (US): J Wiley.

Muhdi. 2009. Struktur dan komposisi jenis permudaan hutan alam tropis akibat pemanenan kayu dengan sistem silvikultur tebang pilih tanam Indonesia. Jurnal Bionatural 11:68-79.

Misra KC. 1980. Manual of Plant Ecology (second edition). New Delhi (IN): Oxford and IBH Publishing Co.

Pamoengkas P. 2006. Kajian aspek vegetasi dan kuantitas tanah sistem silvikultur tebang pilih tanam jalur (studi kasus di area HPH PT. Sari Bumi Kusuma, Kalimantan Tengah. [Disertasi]. Bogor (ID): Program Pascasarjana, Institut Pertanian Bogor.

Pohris H. 2009. Functional Species Composition and Biodiversity Conservation In Managed Forest. Paper presentation at GAForN International Symposium in Dehradun, India. Institute of International Forestry and Forest Product, Dresden University.
[SARPATIM] Sarmiento Parakantja Timber. 2010. Rencana Kerja Usaha Pemanfaatan Hasil Hutan Kayu-Hutan Alam (RKUPHHK-HA) Tahun 2011-2020. Kotawaringin Timur (ID): PT Sarpatim.

Suparna N, Purnomo S. 2004. Pengalaman Membangun Hutan Tanaman Meranti di PT. Sari Bumi Kusuma, Kalteng. Jakarta (ID): PT. Alas Kusuma.

Soerianegara I, Indrawan A. 1998. Ekologi Hutan Indonesia. Bogor (ID) : Laboratorium Ekologi Hutan Fakultas Kehutanan IPB.

Utami SD. 2007. Analisis komposisi jenis dan struktur tegakan di hutan bekas tebangan dan hutan primer di areal IUPHHK PT. Sarmiento Parakantja Timber, Kalimantan Tengah. [Skripsi]. Bogor (ID): Fakultas Kehutanan, Institut Pertanian Bogor.

Whitmore TC. 1998. An Introduction to Tropical rain Forest. England (UK): Oxford University Press.

Wyatt dan Smith J. 1963. Manual of Malaysia Silviculture For Inland Forest II. Malayan Forest Records. (23) : III 4/9 - III 4/13. 